5. Гриценко Е. М. Использование современных BACK-END технологий разработки клиент-серверных приложений [Текст] / Е. М. Гриценко, Е. Д. Иванов, П. С. Шаталов // Научные исследования: теория, методика и практика : материалы IV Междунар. науч.-практ. конф. (Чебоксары, 29 янв. 2018 г.) / редкол.: О. Н. Широков [и др.]. — Чебоксары: ЦНС «Интерактив плюс», 2018.

\title{
Мельниченко В.Н. \\ Риски и отрицательные эффекты внедрения корпоративной системы управления проектами
}

Российский университет транспорта (РУТ (МИИТ))

(Россия, Москва)

doi:10.18411/lj-31-03-2018-15

idsp: 000001:lj-31-03-2018-15

\section{Аннотация}

В данной статье рассмотрены основные проблемы внедрения корпоративной системы управления проектами (КСУП), а так же риски и отрицательные эффекты.

Ключевые слова: управление проектами, КСУП, риски КСУП.

Abstract
In this article, we will review the main problems of implementing a corporate project
management system, as well as risks and negative effects.
Keywords: project management, project management system.

Корпоративная система управления проектами при правильном подходе внедрения на предприятиях, зарекомендовала себя с лучшей стороны, но как любое нововведение она несет в себе различные риски.

Корпоративная система управления проектами (КСУП) - комплекс организационных, методических и информационных средств, поддерживающих процессы управления проектами в организации.

Внедрение КСУП далеко не всегда влечёт за собой положительные эффекты, чаще всего её пытаются внедрить на предприятиях которые не готовы к данной операции, в результате чего затраты превышают прибыль от улучшения процессов.

Есть разные способы, как вводить корпоративную систему управления проектами на предприятии, основных два, а именно:

Первым способом является внедрение КСУП своими силами, то есть руководство привлекает к процессу штатного сотрудника, в этом случае риск заключается в том, что данный сотрудник может быть неопытен в вопросе внедрения и не понимать, зачем это делается, в таком случае данный процесс не принесёт никакого результата. Так как ошибки, допущенные при внедрении, только усложнят процесс управления проектами и увеличат расходы.

Второй способ это привлечение консалтинговой компании, которая непосредственно занимается внедрением, но это тоже большой риск, по причине, что данные компании очень быстро разрабатывают методологию КСУП и так же быстро её внедряют, после чего оставляют заказчика без какой либо поддержки. Результатом является то, что данная система просто разваливается, и не даёт никакого эффекта, в чём и заинтересованы консалтинговые компании[3].

Одной из главных ошибок является непонимание, что такое КСУП. Чаще всего её видят как информационную систему управления проектами (ИСУП) и пытаются внедрить eе, но это в корне не верно, так как основой корпоративной системы управления проектами является методология и проектный офис. ИСУП является вспомогательным элементом, который помогает сформировать портфель проектов, реализовывать их и улучшать методологию, а без чёткой методологии и отдела который занимается данной 
деятельностью, информационная система управления проектами не несёт в себе никакого положительного эффекта, а только затраты на её внедрение.

Также немаловажным риском является непонимание директором фирмы или её менеджером для чего необходима КСУП, вследствие чего, происходит неправильное формирование задач внедрения, и оценки ожидаемого эффекта. В результате появляются неадекватные ожидания участников внедрения и снижение их мотивации на успешный ввод в эксплуатацию КСУП, что приводит к снижению эффективности её работы или же отказу от неё вовсе.

Самой главной проблемой является неготовность самого предприятия, в целом, к внедрению данной системы и складывается это из множества факторов. Например, сама структура предприятия, которая не подготовлена к такому процессу или же не компетенция персонала компании. Также можно рассматривать проблему не компетенции руководства компании или недостаток мотивации сотрудников.

Все эти проблемы ведут к неправильному внедрению КСУП в производство и эффекты, которые планирует получать компания от её использования, стремятся к нулю. Чаще всего они ведут к крупным финансовым потерям компании, а так же качества проектов и кадровых потерь.

Несмотря на высокие риски внедрения, при правильном подходе и анализе проблемы, эффективность внедрения КСУП говорит сама за себя, а именно, что 94\% опрошенных отмечали - увеличение стоимости их организации, 50\% - улучшения исполнения проектов, 36\% - увеличения удовлетворения заказчиков, $54 \%$ - улучшение финансового исполнения, $30 \%$ - общее повышение удовлетворения штатных работников[4].

$$
* * *
$$

1. Разработка функциональной модели информационной системы автоматизации управления деятельностью компании / Медникова О.В., Смирнов С.А., Строев П.С., // eLibrary - научная электронная библиотека [Электронный ресурc] https://elibrary.ru/item.asp?id=29244398

2. Богданов, В. В. Управление проектами. Корпоративная система - шаг за шагом. - М.: Манн, Иванов и Фербер, 2012. - 248 c.

3. Попова М.И. Необходимо ли внедрять КСУП на предприятии. - Электронный научно-практический журнал «Современные научные исследования и инновации» [Электронный ресурс] http://web.snauka.ru/issues/2016/03/65337

4. Корпоративная система управления проектами (КСУП) [Электронный ресурс] http://mahamba.com/ru/korporativnaya-sistema-upravleniya-proektami-ksup

\section{Панченко А.O.}

\section{Анализ и исследование существующих протоколов Интернета вещей}

\section{Дальневосточный федеральный университет} (Россия, Владивосток)

doi:10.18411/lj-31-03-2018-16

idsp: 000001:lj-31-03-2018-16

\section{Аннотация}

В статье приведен краткий обзор протоколов прикладного уровня, наиболее подходящих и часто используемых в концепции интернета вещей (IoT). Рассмотрены их основные достоинства и недостатки, проведен сравнительный анализ по наиболее информативным критериям оценки эффективности сети.

Ключевые слова: Интернет вещей, ІоТ, протокол, М2М.

В последнее время концепция «Интернет вещей» совершила значительный скачок в развитии, так как в современном мире происходит стремление к созданию полностью автоматизированных систем связи, сбора, обработки и анализа информационных данных. 